Journal of Social Sciences 3 (2): 69-77, 2007

ISSN 1549-3652

(C) 2007 Science Publications

\title{
Multicultural Upper Secondary School Life in Denmark: Identifications, Solidarity and Citizenship
}

\author{
Yvonne Mørck \\ Department of Society and Globalisation, Roskilde University, Denmark \\ P.O.Box 260, DK 4000 Roskilde
}

\begin{abstract}
Education has played an important role in the development of the Nordic welfare states. As in other European countries, present day Denmark wrestles with the problem of finding ways to handle the increased diversity of its population in terms of, for instance, ethnicity, religion and language. Hence, negotiations and contestations about how to operationalize different forms of multiculturalism on all sorts of multicultural issues are currently on the agenda in relation to the welfare state. This article explores the interaction between ethnic majority and ethnic minority students in an upper secondary school as a micro-sociological laboratory of the multicultural processes and developments taking place in society at large. It is recommended to reflect upon and implement different strategies that could support a 'citizenship education' which is needed in order to advance the cohesion of the Danish welfare state in the years to come.
\end{abstract}

Key words: Nordic welfare state, ethnic minority youth, multicultural issues, citizenship education

\section{INTRODUCTION}

As other European countries, Denmark wrestles with the problem of finding ways to handle the increased diversity of its population in terms of, for instance, ethnicity, religion and language. Hence, negotiations and contestations about how to operationalize different forms of multiculturalism on all sorts of multicultural issues are currently on the agenda in relation to the welfare state $[2,3,11]$. One of the main questions is: How can more individuals and groups be included in active citizenship and thereby contribute constructively to the community of solidarity which the welfare state constitutes? Education has always been a means to social mobility and integration. Historians who have studied the development of the Danish welfare state have maintained that in the "pre-welfare state' i.e. the period before World War II, social policy and education policy constituted major components in the integration of the working class. This integration was an important element in the construction of the modern welfare state that was created after the war ${ }^{[1]}$.

Denmark has a population of 5.3 million. Compared to many other nations Denmark has been very homogeneous for instance ethnically and religiously. 1.1.2006 463,235 immigrants, refugees and their descendants live in Denmark $(8,5 \%$ of the population). Now more than 200,000 people with roots in the Muslim world live in Denmark. Guest workers from respectively Turkey, the former Yugoslavia and Pakistan (and their descendants) are the three largest immigrant groups whereas refugees mainly come from the Arab world such as Iraqis and Palestinians, Bosnia, Iran and Somalia. There are also refugees from for instance Vietnam, Chile and Sri Lanka. The educational level is more varied among refugees than among guest workers and their wives. However, especially many of the women from both categories have little or no school experiences.

If we look at present day Danish upper secondary schools, they have experienced an increased intake in new groups of students from both ethnic majority and ethnic minority backgrounds, particularly during the last decade. New forms of intersections of diversity and social stratification - hitherto unknown in this area of youth education - have therefore been placed on the agenda. The range and diversity among the students in terms of their social class, ethnicity, nationality, mother tongue, religion and lifestyle has increased considerably. Consequently, an unprecedented proportion of the student population is composed of 'class travellers', i.e. they are the first members of their families to have got this far in the education system $[4,5,6]$. Thus, it seems relevant to examine the more or less explicit negotiations among school agents (i.e. students as well as teachers) about how to function

Corresponding Author: Yvonne Mørck, Department of Society and Globalisation, Roskilde University, Denmark, P.O.Box 260, DK 4000 Roskilde, Tel: +45 46742000 
together both professionally and socially. These processes can illustrate the multicultural developments taking place in society at large, i.e. upper secondary schools can be seen as a micro-sociological laboratory. Some of tomorrow's adult citizens meet in upper secondary schools and are, to varying degrees, influenced by it and the education they are part of. This implies that upper secondary schools play a vital role in what could be termed 'citizenship education', including the development of which identifications, values and forms of solidarity that the youngsters want to associate with.

I use the categories ethnic minority student, minority student, minority youngster and ethnic majority student, majority student, majority youngster respectively while being aware of that the categories are heterogeneous as well as each individual is positioned through an intersection of different identifications based on e.g. gender, class, ethnicity, age, sexuality [see e.g. $7,8,6]$. Thus, every individual is always more than their ethnic identification. One may look for what category of person is 'minoritised' in which situations, contexts and discourses which again depends on the dominating power and hegemony relations, i.e. that some have power to place others in a minority position [9]. Further, “...'minorities' are positioned in relation not only to 'majorities' but also with respect to one another, and vice versa. Moreover, individual subjects may occupy 'minority' and 'majority' positions simultaneously..." [9, page 189].

\section{MATERIALS AND METHODS}

I conducted fieldwork in two different kinds of upper secondary schools in the Copenhagen area: An ordinary upper secondary school and an upper secondary school with a business curriculum programme. Both types of school programmes consist of three years of schooling and qualify graduates for admission to higher education (age group: 16-19 years). The fieldwork took place in the second year of the programme and over a 31/2-month period (1999 and 2001 respectively). It included observations in five classes, participant observation among students and teachers outside lessons, essays written by the students on the theme of 'the multicultural upper secondary school', photographs of everyday life at the respective schools taken by selected students with disposable cameras, and 65 interviews with students, teachers, student advisers and a headmaster. In both schools, approximately 30 percent of the students were drawn from ethnic minorities, most of whom hailed from a non-Western, Muslim background; however, some had roots in, for example the former Yugoslavia, the Philippines, China or South America. Most of these young people had grown up in Denmark, although some had arrived as refugees during childhood.

As a point of departure I will present two narratives of exclusion and non-recognition as well as a conceptual framework for analysing these examples. The aim is to take some of the student's concrete experiences with each other as well as some of their perceptions of each other seriously. In the last part of the paper, a theoretical framework will be presented that hopefully will contribute to a new perspective on the field of study which transcends the empirical examples. Finally, some concrete strategies or initiatives will be presented - strategies which could be an important part of a 'citizen education'.

\section{RESULTS}

Costs of interaction: The study tour and the grill party: Students with majority and minority backgrounds interact rather peacefully at the school. However, they live in what one can call 'parallel worlds' which seldom intersect. They often speak briefly and abruptly with each other; they can work together in class, especially when the teachers tell them to. At the same time as the students declare great satisfaction about the school almost everybody interviewed was dissatisfied with the obvious division between majority and minority youngsters. Both groups of students explained the divide by saying that the two youth groups have different interests and therefore not so much in common and not so much to talk about. The separation is not due to dislike of each other or that they cannot cooperate in class, they explained in the interviews. Both categories of students - but not least ethnic minority students as they from both a social point of view and at the school at large are in a minority position - seem to take into consideration what has been called 'costs of interaction' ${ }^{[12]}$. This concept might help us explain why majority and minority students live in parallel worlds. Costs of interaction imply that it can cost emotionally and psychologically to interact with people who in some respects have other values, norms, behaviour, priorities, religion etc. than oneself. If individuals with different cultural backgrounds must communicate and for instance work together, then all involved take some chances if they do not know each other's culture and language sufficiently. The probability to get to misunderstand each other, not only linguistically, but also culturally is much higher than in mono-cultural situations. Thus, a way to keep down the costs is to interact with people who have what 
one broadly can call a similar culture; in other words people who are like oneself. This strategy is well known: Most people to a greater or lesser degree interact with and marry persons who for instance have the same nationality as well as similar socio-cultural background and levels of education.

I use the concept cost of interaction in a way that is inspired by the understanding of 'strategy' developed by Pierre Bourdieu: Strategy should not necessarily be understood as a conscious and rationally formulated act or behaviour. However, human beings, i.e. the youngsters are acting according to certain dispositions developed through their socialization. These dispositions incline them toward certain behaviour which in the situation will seem 'natural'. Although some agents have been exposed to similar conditions through their upbringing, thus having developed similar dispositions, their strategies can be quite different. Also some agents will try to change the rules in order to gain a better position in the dominating power game [13]; in this case e.g. through the interaction among the students $[8,6]$.

To turn to the two empirical examples: First the narrative of the study tour where some ethnic minority students felt excluded. Students from different classes were on a five day-trip. As part of the curriculum, the classes visited several companies and representatives told about their production. One of these representatives was called Mr. Koch. In English the word 'cock' refers to the male sexual organ, which some of the ethnic majority boys made fun of the rest of the trip. They, for instance, put their hands on their own sexual organs every time they referred to Mr. Koch. One evening they had been drinking and sang some shameless songs. Several of the minority girls were upset by this behaviour which one of the girls mentioned to Mikkel, one of the dominant majority boys. He was surprised by the criticism and uneasiness expressed by the girl.

In the grill party story, it was ethnic majority students who expressed a feeling of exclusion. A majority boy, Paul, invited everyone in his class to a grill party at the end of the first year in upper secondary school. Half of the students had different minority background and the other half consisted of majority boys (no majority girls). In addition to Paul, a Chinese girl and a girl who was half Danish and half Arab planned the party. The youngsters had two grills, so the students with Muslim roots could have halal-meat on one and the non-Muslim students could use the other. Besides beer, there were soft drinks for those who preferred them. None of the students with Muslim roots had explicitly said that they would not come to the party. However, none of the minority students turned up
- except the two who arranged the party. As Paul told me the story, he expressed disappointment. He felt that the ethnic minority students did not want to participate in common activities together with ethnic majority students; not even when special considerations were taken.

If we revisit the narratives of the study tour and the grill party with the concept of costs of interaction as an analytical tool which interpretation is then offered? Even though one has to take into consideration that joking about sexual issues probably has to do with the specific age group and that some youngsters regardless of ethnic background could feel embarrassed by it, such behaviour is given another meaning when ethnic minorities - in this case minority girls - are involved.

Rosa who acted as a mediator between the majority boys and the minority girls has roots in South America and she has Catholic background. However, although the other minority girls and boys have different ethnic and national roots, most of them have a Muslim background. Thus, Rosa can be seen as a kind of border figure or border crosser. This interpretation is supported by the fact that when she told me the Koch-story she expressed ambivalence: Although she would not make that kind of fun herself, she understood this sense of humour. Also, she argued, the ethnic majority youngsters had been drinking. However, she could also understand that some of the girls with Muslim background felt awkward because she herself felt the behaviour embarrassing. When she says that Mikkel "...thought that they...we did not have anything against the joking...but they opposed it very much" Rosa again reveals her own in-between-position: First she says "they" about the minority students, then she says "we" and finally she says "they" again. Thus, she both includes and excludes herself in the ethnic minority category.

Mikkel said to Rosa, "why do they [the Muslim students] not just say that they don't like it? Then we would have gone somewhere else. Why do they always talk behind one's back?". Rosa agrees that majority youngsters often say their opinion more explicitly than what she has experienced among minority youth. In her interpretation this is due to the fact that minority youngsters do not dare to express their opinions because there would be a risk of conflict. What does Rosa mean when she says that minority students want to keep peace in class? Although all young people in Denmark have late modernity as a basic condition, several potential fields of conflict seem to exist between the two categories of students. Among other things, late modernity involves a gradual dissolution or disintegration of the traditional world, values and ways 
of life as well as an increase in individualization and reflectivity respectively ${ }^{[3,11,15,16]}$. Both parties try more or less consciously to keep what they experience as controversial issues under control. A major area of conflict concerns how the two groups of youngsters live their youthful lives, especially how they 'do' gender and sexuality and their relationship to alcohol. Other important fields of conflict include questions about family relations and solidarity as well as Islam and more broadly the status of religion in a late modern life. Thus, we could ask, what are the costs of interaction seen from the perspective of respectively majority and minority students? When is the interaction perceived as costing too much and when is the 'price' acceptable? Generally, my data suggests that most ethnic majority youngsters find the lives that ethnic minority youngster lead rather strange. According to Mikkel, especially minority students with Muslim roots, “... are not as liberated as us [majority students]". By liberated Mikkel refers to phenomenon like having sexual relations; teasing each other in a sexualized form without anyone taking offence; that majority students in professional contexts can talk about erotic themes, i.e. in Danish literature as well as they can drink alcohol and go out. In his own way, Mikkel is talking about the disintegration of more traditional gender perceptions and ways of life. Most of the minority students have roots in the non-Western Muslim world and often their families come from rural areas having few or no experiences of school (especially the women). Among such minority families it is an ideal not to have sex before marriage as well as not to drink alcohol. This is very hard for most majority youngsters to comprehend as precisely sexual relationships and drinking are some of the core themes in their lives - actually young ethnic Danes are the youngsters in Europe that drink the most. The social control of, especially, girls and women that is widespread among ethnic minorities seems unacceptable for most majority youngsters. Generally, women among the relevant ethnic minorities are perceived by both sexes as embodying cultural continuity and as carriers of culture and traditions from the country of origin. Thus, the expanded family tries to keep what is implicitly perceived as the 'human fields', namely women's sexuality and reproduction within the boundaries of this family $[17,18,19,10]$. Also, religion usually plays a bigger role for minority youngsters than for most majority youth. Due to the fact that they are exposed to a least a double pressure from the ethnic majority society and the Muslim community respectively even so called cultural Muslims have to reflect upon their relationship to Islam in order to position themselves in relation to a religious identification. However, most majority youngsters find it very difficult to understand that one's life should be determined in greater or lesser degree by a religious grounded set of rules that has its roots in a book from the 600th century, as one student expressed it. I would expect that the youngsters would express a similar attitude towards majority youngsters who take religion so seriously, would it be Christianity (e.g. Jehovas Witness) or Islam, that it would steer their youth life in other directions than the mainstream youth culture.

Similarly, there is a tendency among ethnic minority youngsters to look with scepticism upon the life that most of the ethnic majority youngsters live. This life is often interpreted as sexually promiscuous, without tight friendships and dominated by alcohol. Majority youth can also be seen as lacking a moral stand(ard) as well as moral rules, due to the fact that they do not respect religious values very much. Finally there is a perception of a lack of affiliation, respect and loyalty between majority youngsters and their families [see also 10].

However, as many ethnic minority youngsters have had most or all their upbringing in Denmark, differences in experiences as well as socio-cultural differences between generations have evolved ${ }^{[10 \text {, see also }}$ $20,21,22,15,16]$ one could argue that the youngsters develop different forms of 'alternative modernities' ${ }^{[33]}$. In posttraditional societies generation gaps will often arise, but it seems that in contemporary minority families this tendency is increased. For instance, it seems that minority youngsters would like to see increased democratization in the family in the sense that they would like to reduce the generation and gender hierarchies, including wanting more autonomy in their choice of spouse. Further, certain dimensions of young people's late modern city life are also attractive for the minority youth, for instance the exploration of spaces of leisure such as cafes, cinemas and discos. Hence, they develop different, partly gender specific, strategies in order to combine several more or less different sociocultural arenas. In other words, they try to keep the costs of interaction down in relation to majority members like majority students and teachers as well as in relation to their family members, especially their parents. One consequence of this is that some minority youngsters can have a hard time and maybe an impossible time telling the truth about their behaviour and obligations in upper secondary school and at home in the two different arenas. This may lead to telling 'white lies' in both places. Especially for girls, a strategy could be a seeming accept of going to a party or a study tour in the hope that the parents in the end will allow it. But this may not happen and then the girls have to stay 
away from the activity - sometimes without excusing themselves. Maybe they think it is embarrassing or painful that they not are allowed to participate and do not talk about it. Or they do not give the correct explanation to the teachers and majority students. Another possibility is that they have other reasons not to participate, for example they feel that there is too high a 'price' to be paid by the interaction in relation to parents, majority youngsters or both parties. Also, some minority students of both sexes (often the more religiously orientated) do not like to be in the company of majority or minority students that drink alcohol. Thus, they keep away from, for instance, parties at school or private parties. However, it is more difficult for them to keep away from other students who drink on a study tour. Most teachers accept drinking on a study tour as long as the students do the required work (all the teachers at this upper secondary school have an ethnic majority background).

The analyses of the study tour also illustrates that some minority girls felt uneasy about and excluded by the behaviour displayed by certain majority students. A minority student like Rosa may also have been worried that some of this behaviour would 'rub off' onto her in the sense that she would be in danger of getting categorized with the youngsters whose behaviour she somehow wanted to distance herself from.

One could imagine that the students with Muslim background did not participate in the grill party because they felt that they had to pay too high a 'price' for interacting with ethnic majority students and ethnic minority students who seem more willing to adapt to majority youth culture and majority culture (more) generally. In this interpretation, the narrative of the grill party can be seen as an example of how majority students not only felt, but in fact were, excluded or rejected by minority students. Such an experience is especially frustrating for majority students such as Paul who make an active effort to include minority youngsters. Such experiences can create (more) campthinking or camp mentalities ${ }^{[23]}$. Because although Paul says that minority students will be invited to coming parties, he and other majority students may reconsider that decision: Do they want to run the risk of being rejected again? Such reflections can more or less consciously lead to the conclusion that the costs of trying to interact are too high. Hence ethnic majority students will stick to themselves.

Strategies of identification: It is however not only between ethnic majority and ethnic minority students that the costs of interaction are on the agenda but also among what is considered as 'one's own kind'.
Kurdish-Iraqi Mona escaped as a child with her family to Denmark. As with many other students Mona would like the relationship between the majority and minority students to improve, but she thinks that minority students are afraid of not being accepted by majority youngsters; she expresses 'recognition-worries'. And, as Mona says, when ethnic minority youngsters feel (more) at ease and confident in the company of each other, why bother mixing with majority youth? Some ethnic minority students give Katarina, a refugee from Bosnia, the negative label of a 'wanna-be-Dane' due to the fact that she hangs out with the few ethnic majority students in class, attends parties and has a majority boyfriend. Seen from the perspective of other ethnic minority students Katarina 'looses' some of her ethnic identity by interacting with majority students who from such a standpoint are seen as 'the wrong ones'.

In the interviews, both Mona and Katarina are critical towards some of the other ethnic minority students whom they think show a lack of initiative and interest in interacting with ethnic majority students. Thus, the two girls express a lack of understanding of some minority youngsters who were born in Denmark especially those who have taken up a more or less radical religious identification, like girls with headscarves. However, Mona and Katarina explain that the criticism goes both ways. When they talk about certain subjects like school parties, some of the "...headscarf-girls make very, very bad remarks" even before the relevant party has taken place, says Mona. She explains that before a party at school, " ....then they started saying all kinds of things... They made fun of me by saying that one should be integrated and why a foreign girl wants to participate in such parties at all". However, they agree on one thing: education is important. Nevertheless, Mona talks and interacts with these girls because she does not want to create conflict in "our circle of friends" as she described it.

Thus, ethnic minority students share a minority position and they try to support each other. In the interviews many minority youngsters reflect upon the importance of having a common social space in the upper secondary school in which they can feel 'safe' ('trygge'). This can be interpreted as a wish for a safe haven where they do not have to explain or feel they have to explain about their background, why they think, feel, behave and react as they do. In other words, many ethnic minority students seek confidence in a certain homogeneous community whereby the costs of interaction are lowered compared to interacting with ethnic majority students. However, some minority youngsters - like Mona and Katarina - who trouble such border-drawing pay a 'price' of interaction with 
other minority students who are less interested in or less daring in their interactions with the majority youth. And Rosa who mostly hangs out with students with a Muslim background had to learn that being a border figure places her in a vulnerable position. In this group, where she imagined she was included on equal footing, she experienced that some of the boys made advances toward her - a conduct the Muslim boys do not display in relation to the Muslim girls in the group.

Mona, Katarina and Rosa are positioned in a contested field between 'a hyphenated identification' and 'a creolized identification' [paraphrase of 24]. Hyphenated identification implies that the youngster tries to build a bridge between two separate categories, such as e.g. Iraqi and Danish. Due to her background and family bonds Mona has to relate to what can be called an Iraqi frame of understanding while in the upper secondary school she displays a type of behaviour that to a great extent is cultural recognizable for majority students and teachers. However, the creolized choice of identification is characterized by a permanent ambivalence as well as a pressure to choose; it is such a hybrid that it is not possible to talk about neither pure separate cultures nor hyphens and borders. Mona's position is reflected in her intense concern about moving to a small apartment on her own. After long discussion with her parents, they have accepted her wish. The fact that Mona herself wants to live alone as well as her family accepting it represents complicated identification work, especially when one keeps in mind that women often are perceived as creatures who embody cultural continuity and whose sexuality and reproductive capacity have to be controlled by the family. Although all three young women take up a position as a minority in the upper secondary school among a majority of ethnic majority students, Katarina and Rosa are in a different situation than Mona. Although it varies how important Islam is in their lives, the common religious foundation and the minority position it places the youngsters with Muslim roots in, creates an important background for their identification and social interaction; this is also the case for Mona. However, both Katarina and Rosa can be interpreted as border figures in the sense that they are cultural Christians among a majority of ethnic minority students with Muslim background. Due to a combination of her appearance - blonde hair, fair skin and average height and her European and religious roots - Katarina can pass as an ethnic Dane, i.e. she can slip imperceptibly into the majority category. Rosa however, due to her appearance - black hair, dark skin and short - does not have that option.

\section{DISCUSSION}

Identification choices as solidarity choices: Many different kinds of transformations are taking place in the wake of late modernity. An important one is that a reflexive form of solidarity is advancing at the same time as more traditional forms of solidarity such as the emotional and the conventional ones are deteriorating. An emotional form of solidarity is based on intimate and face-to-face-relations between, for instance, family members and friends. The responsibility of each person is limited to such 'Concrete Others'. A conventional form of solidarity is based on common interests, struggles and goals that unite people as members of a group such as trade unions. This means the existence of an internal responsibility between members of relative homogeneous groups. However, the reflexive form of solidarity transgresses the excluding limitations which characterize the two first forms of solidarity. Thus, traditional forms of solidarity seem inadequate in a strongly differentiated society in which people are getting more and more dependent on each other in-spite of their differences. Hence, the reflexive form of solidarity contains a more reflexive approach to moral obligations and is more unlimited that the traditional forms, i.e. it rests on the recognition of the difference of other citizens. Reflexive solidarity is built on open and communicative ties which assign the possibility of responsibility and acceptance of difference and thus represents a bridge between the individual identity and universality ${ }^{[25]}$.

Other researchers express similar ideas when they argue that identity choices are solidarity choices and when they use concepts like 'a post-ethnic perspective' ${ }^{[26]}$ and 'ethnic options' ${ }^{227,28]}$. The dimension of choice is especially relevant in a late modern world in which there is a great symbolic value in terms of identity and identification. According to a post-ethnic perspective, a prominent characteristic of our era is exactly a preoccupation with affiliation, i.e. a concept that suggests a great measure of flexibility, performativity and social dynamic. The claim is to support a choicemaximizing principle in relation to people's choice of communities and affiliations to different groups, i.e. ethnic options. Hence, this position is for commitment and the right to exit whatever group but reacts against prescribed affiliations on the basis of descent. Having said that, a post-ethnic perspective also recognizes that choices are made in specific, limiting circumstances; that is human beings make their own history, but under circumstances directly encountered, given, and transmitted from the past. Finally, this perspective 
challenges that affiliations based on choice are somehow artificial and lacking in depth compared to those based on ordinance of blood and history. Thus, a post-ethnic perspective represents a critical renewal of a 'rooted cosmopolitanism' in the context of the contemporary greater sensibility to roots ${ }^{[26]}$.

In a complex late modern world there is a tension between on the one hand the protection of the cohesion of a society, i.e. protection of the solidarity across an increased diversity and on the other hand the support to the self-realization of each citizen. However, I will argue that as a normative ideal, the post-ethnic perspective implies that each individual (such as the students) can opt for a reflexive solidarity without letting go of commitments and obligations towards different kinds of group and personal affiliations respectively (i.e. conventional and emotional solidarity). Such a perspective makes it possible to take what I elsewhere have termed 'a reflexive multi-critical position', i.e. to be critical of all positions, perspectives and interpretation regardless of who 'occupy' them and express them ${ }^{[3]}$ or to operate with an 'intersectionality' perspective, i.e. to be critical of different systems of domination simultaneously such as patriarchy, ethnic majority domination and racism ${ }^{[7,9,29,6]}$. A post-ethnic perspective also makes it possible to develop creolized and intersecting identifications leaving more space of maneuvering in complex and unknown waters. In other words, a choice-maximizing principle that still values solidarity and affiliations should be possible. Individuals, regardless of background, can find security within their different groupings but they also have the ability to transcend these affiliations. One can decide to destabilize the parallel worlds, thus challenging the costs of interaction. This is decisive, because there are also costs of not interacting which can be detected at micro-levels such as in an upper secondary school as well as on a societal level: If one does not try to build bridges across differences, it will have negative consequences for the cohesion of the relevant context. An increased interaction does no mean the end of all disagreements or differences, but debates, contestations and struggles for recognition and inclusion ought as a starting point take place in a democratic environment where one listens to each others' the arguments ${ }^{[\text {e.g.30]. }}$.

This argument leads to the concluding remarks. I will suggest that an important investment in the future and thus in securing the Danish welfare state - is to develop what one could term 'citizen proficiency' or a 'citizen education with a multicultural and a multiculturalism-approach' as part of the upper secondary school curriculum. I will suggest three main strategies that could advance the diversity management in youth education (these initiatives should be seen as an enlargement of existing policies as well as a contribution to the development of new ones). The first strategy is related to point about creating a democratic learning environment. Part of that could be to formulate or draw up a common project with the aim of creating a physically clean, agreeable and safe environment at the upper secondary school where the majority of the students like to be because they feel respected by each other and the teachers. As part of the education, it is expected that the students work together across their internal differences about projects that exceed themselves. Thus, an important ambition could be to make the upper secondary school (re)present what has been termed 'a good otherness', i.e. that is provide the students with something that is different from what everyday culture convey to them ${ }^{[31]}$. In other words, the aim should be to 'make something' rather than to 'make someone' out of the youngsters ${ }^{[5]}$. This implies that professionalism has first priority in the sense that it becomes a common project to make the upper secondary school a place in which - regardless of background and other components of difference - the students learn to learn. If this is going to succeed it is important that there is quiet during lessons - both concretely and in the sense of safety, i.e. that no one has to or feels that (s)he has to explain and defend their complex identifications.

A second strategy would involve that the headmaster and teachers continuously present the students with an explanation of what is expected professionally and socially when one is positioned as an upper secondary school student. This implies presenting the common values and the rules of the upper secondary school as well as the obligations, which is attached to this form of youth education. Such common values and rules, which in accordance with the reflexive solidarity should be group transcending, ought not to be static. Rather the values and rules should continuously be reflected upon in order to make the school function as well as possible professionally and socially. Also, the different initiatives should be grounded in theory of education as well as in the experiences of the teachers of how to cope with increased diversity in the specific context. A greater transparency in relation to expectations, obligations and rights would support not least the students who are class travellers and/or ethnic minority students due to the fact that they will be in a better position to see through the 'silent curriculum', i.e. the perceptiveness which dominates the youth education professionally, socially and in relation to expected behaviour. 
An issue that seems relevant to take up is whether it is appropriate that students and teachers drink while being on a study tour. Does it signal professionalism and a space for learning? Also, as there are students who do not have alcohol as part of their way of life (i.e. many students with Muslim background) as well as ethnic majority youngsters should learn how to manage the use of alcohol, it would be worth a discussion [see 32]. Also, one could discuss and work out a policy regarding the increased sexualized communication and behaviour that is part of not least ethnic majority youngsters' youth culture (i.e. Mikkel's comments as well the Koch-story).

The aim of the third initiative is to present the teachers as well as the students with some analytical tools that will support them in coping with intercultural phenomena, intercultural communication and the intersection of different forms of domination. This could include a historical, theoretical and practical knowledge of a range of concepts and processes that would enable both teachers and students to analyze some of the processes of inclusion and exclusion they themselves are involved in as well as on a larger scale. For instance, in order to operate with a reflexive solidarity and a post-ethnic perspective it is important to acknowledge that one can perceive culture as a process rather than as a static essential phenomenon, which has to be defended.

As mentioned in the beginning of the paper, one can perceive upper secondary schools as a microsociological laboratory for larger societal processes. This implies that the initiatives involve great challenges as well as promising potential. The question is not whether such strategies should be implemented but rather what they should contain and how to tackle them in order to succeed in the main project: The protection and the advancement of the cohesion of the Danish welfare state in the years to come.

\section{REFERENCES}

1. Christiansen, Niels Finn and Petersen, Klaus, 2004. Velfærd med vilje - men hvis? In: Den danske velfærdsstats historie (eds N.Ploug, I.Henriksen and N. Kærgård), pp.142-171. København, Socialforskningsinstituttet 05:18.

2. Hall, Stuart, 2000. Conclusion: the Multicultural Question. In: Un/Settled Multiculturalisms. Diaspora, Entanglements, Transruptions (ed B.Hesse), pp. 209-241. London, Zed Books.

3. Mørck, Yvonne, 2002. Multikulturalismernes kønsblinde øje. Mangfoldighedsudfordringer og kønsligestilling. Dansk Sociologi vol.13, nr.3:7-25
4. Trondman, Mats, 1994. Bilden av en klassresa. Sexton arbetarklassbarn på väg till och i högskolan. Stockholm, Carlssons.

5. Frykman, Jonas, 1998. Ljusnande framtid! Skola, social mobilitet och kulturell identitet. Lund, Historiska Media.

6. Mørck, Yvonne, 1996. Why not intersectionality? A concept at work in modern complex societies. Intersectionality and class travels. FREIA: Feminist Research Center in Aalborg, Institute for History, International and Social Studies. Paper No. 61, pp.1-21.

7. Crenshaw, Kimberlé Williams, 1994 (org.1991). Mapping the Margins: Intersectionality, Identity Politics, and Violence Against Women of Color. Stanford Law Review 43 (6): 1.241-1.279.

8. Mørck, Yvonne, 2003. Narratives of the intersections of masculinities and ethnicities in a Danish high school class. NORA: Nordic Journal of Women's Studies Vol. 11, Nr.2: 11-121.

9. Brah, Avtar, 1996. Cartographies of Diaspora.Contesting identities. London, Routledge.

10. Mørck, Yvonne, 1998. Bindestregsdanskere. Fortællinger om køn, generationer og etnicitet. Frederiksberg, Forlaget Sociologi.

11. Mørck, Yvonne, 2001. Etniske minoritetsunge og demokratisk medborgerskab. In: Køn, demokrati og modernitet. Mod nye politiske identiteter (eds A.Christensen and B.Siim), pp.223-237. København, Hans Reitzels Forlag.

12. Necef, Mehmet Ümit, 2000. Etnisk kærlighed i etnisk cyberspace. Information om indvandrere, tidsskrift for migration og kulturanalyse nr.4. Center for Mellemøststudier. Odense: Syddansk Universitet, pp.1-4.

13. Bourdieu, Pierre \& Wacquant, Loïc J.D., 1992. An Invitation to Reflexive Sociology. Cambridge, Polity Press.

14. Giddens, Anthony, 1990. The Consequences of Modernity. Cambridge, Polity Press.

15. Prieur, Annick, 2002. Magt over eget liv: om unge indvandrere, patriarkalske familieformer og nordiske ligestillingsidealer. In: Kønsmagt under forandring (eds A.Borchorst), pp.149-167. København, Hans Reitzels Forlag.

16. Prieur, Annick, 2004. Balansekunstnere. Betydningen av innvandrerbakgrunn i Norge. Oslo, Pax Forlag A/S.

17. Delaney, Carol, 1991. The Seed and the Soil. Gender and Cosmology in Turkish Village Society. Berkeley, University of California Press.

18. Yuval-Davis, Nira, 1997. Gender and nation. London, Sage. 
19. Espín, Oliva M., 1997. Latina Realities. Essays on Healing, Migration, and Sexuality. Oxford, Westview Press.

20. Røgilds, Flemming, 1995. Stemmer i et grænseland. En bro mellem unge indvandrere og danskere? København, Politisk Revy.

21. Necef, Mehmet Ümit, 1996. Ethnic identity and language shift among young Turks in Denmark. Ph.D.Dissertation. Odense, Center for Contemporary Middle East Studies. Odense University.

22. Tireli, Üzeyir, 1999 Hverdagens erobring. Etniske minoritetsunge i europæiske storbyer. København, Hans Reitzels Forlag.

23. Gilroy, Paul, 2000. Between Camps. Nations, Cultures and the Allure of race. London, The Penguin Press.

24. Eriksen, Thomas Hylland, 1999. Hybrid kreativitet. In: Ambivalens og fundamentalisme (eds T.H.Eriksen and O.Hemer), pp.9-22. Oslo, Spatacus Forlag.

25. Dean, Jodi Dean, 1996. Solidarity of Strangers. Feminism after Identity Politics. California, University Press.
26. Hollinger, David, 2000. Postethnic America. Beyond Multiculturalism. New York, Basic Books.

27. Waters, Mary, 1990. Ethnic Options. Berkeley, University of California Press.

28. Song, Miri, 2003. Choosing Ethnic Identity. Cambridge, Polity Press.

29. Mørck, Yvonne, 2005. Intersektionalitet og diversitet: Fadime-sagen. In: Kultur på kryds og tværs (eds H.Bech and A.Scott Sørensen), pp.6587. Århus, Klim.

30. Bauman, Zygmunt, 2001. Community: seeking safety in an insecure world: Themes for the $21^{\text {st }}$ century. Cambridge, Polity Press.

31. Ziehe, Thomas, 2004. Øer af intensitet $i$ et hav af rutine. Nye tekster om ungdom, skole og kultur. København, Politisk Revy.

32. Skrowny, Maja, 2005. Alkohol, identitet og fællesskaber - i et integrationsperspektiv. Center for Ungdomsforskning/DPU, Ungdomsforskning nr.3.

33. Gaonkar, Dilip P., 2001. On Alternative Modernities. Public Culture vol.11, no.1: pp.1-18. 